IJTC

Ilomata International Journal of Tax \& Accounting

P-ISSN: 2714-9838; E-ISSN: 2714-9846

Vol. 1 No. 2 March 2020 Pp : 115-121

https://www.ilomata.org/index.php/ijtc

\title{
Does The Value of the Company Affected Intellectual Capital with Financial Performance as Interesting Variables?
}

\author{
Rio Ahmad Junaedi ${ }^{1}$, Elva Nuraina ${ }^{2}$ dan Nur Wahyunig Sulistyowati ${ }^{3}$ \\ 1FKIP, Universitas PGRI Madiun, Indonesia \\ 2Pendidikan Akuntansi, Universitas PGRI Madiun Indonesia \\ ahmadrio120696@gmail.com
}

Submitted : Jan $13^{\text {th }} 2020 \quad$ Revised $:$ Feb $13^{\text {th }} 2020 \quad$ Published $:$ March $30^{\text {th }} 2020$

\begin{abstract}
This study aims to examine the effect of intellectual capital on firm value through financial performance as an intervening variable in the property and real estate sub-sector companies which is quantitative research by applying hypothesis testing and conducting path analysis using linear regression. To test the influence of mediation in this study applying the sobel test with the results of financial performance cannot mediate the relationship of intellectual capital and firm value because financial performance is not the only factor that influences the movement of company values, and intellectual capital itself is a factor that cannot be measured directly different from financial performance.
\end{abstract}

Keywords: Intellectual Capital, Company Value, Financial Performance.

\section{INTRODUCTION}

At present the growing variety of investments is investing in land or property which has an impact on the high level of development of the property and real estate industry plus more and more companies are participating in taking advantage of this opportunity (Hamidy, Wiksuana, \& Artini, 2015). In the business world, a company must be faced with conditions where an increase or decrease in the value of the company. The stock price index experienced a decline in early 2018, one of which was the property sub-sector companies cited through RTI Buisness namely PT Bumi Serpong Damai decreased by 75 points to $4.09 \%$ or Rp 1,760. PT Alam Sutera Realty decreased 18 points to $4.55 \%$ or Rp. 378. PT Ciputra Development has decreased by 40 points to $3.01 \%$ or Rp. 1,290. PT Agung Podomoro Land has decreased by 12 points to $5.31 \%$ or Rp. 214. PT Lippo Karawaci, which decreased by 30 points to $5.61 \%$ or Rp. 505. PT Summarecon Agung also decreased by 45 points to $3.81 \%$ or Rp. 1,135. IDX Director Tito Sulistio stressed that the weakening was caused by perceptions originating from the state of the world economy, namely the United States, if the company's output in 2017 was good the economy would be good. All perceptions are only temporary due to good economic and corporate fundamentals (Ningrum, 2018). With this phenomenon, it encourages researchers to find out about the weakening of company performance and value in the property and real estate sub-sector companies, is it because the company is not maximally utilizing the existing wealth (tangible and intangible assets), namely intellectual capital, because some theories state that intellectual capital is the most important part in increasing a company's wealth. 
Does The Value of the Company Affected Intellectual Capital with Financial Performance as Interesting Variables?

Junaedi, Nuraina, Sulistyowati

Intellectual Capital is no different from the insights and expertise inherent in the organization of the intellectual community, intellectual capital can also be said to be a high-value resource and has the ability to take action based on knowledge as conveyed by Ulum (2009) and if intellectual capital is used to its full potential, has an impact on the quality of the company's financial performance where the financial performance itself is the same as the analysis carried out to find out how far the company operates its business based on effective and efficient financial implementation standards in the opinion of Fahmi (2018) which as a whole influences the movement of company value, its relation with this topic is a reflection of the price to be paid by potential buyers if the related company is to be sold, because in essence the value of the company is the perception of all investors in the position of success value that is often linked with stock value and profitability as stated by (Brigham \& Houston, 2010).

Judging from the discussion above, several previous researchers have conducted intellectual capital, company value, and financial performance studies such as Sudibya \& Restuti (2014) which empirically proved that intellectual capital has a positive influence on financial performance, in contrast to Andriana's (2014) research which states that Intellectual Capital and Human Capital have insignificant negative effect on financial performance, even though Employed Capital and Structural Capital show positive coefficients.

The different results of research conducted by several researchers such as Sudibya \& Restuti (2014) states that intellectual capital has a positive influence on financial performance, in contrast to Andriana (2014) which provides a statement that Intellectual Capital and Human Capital insignificantly have a negative effect on financial performance. This encourages researchers to carry out the next research that is the application of ROA as a measure of financial performance which is used as a connecting variable of the two other variables as well as researched data focusing on property and real estate sub-sector companies that are incorporated in the BEI period 2015 to 2017 because the related sectors have the lowest movement in the stock price index while the price of the property is getting higher and this becomes more interesting to study because the development of the Property and Real Estate sector is part of the indicator of economic growth in Indonesia in particular.

Some of the explanations above, then this study aims to examine the influence of intellectual capital on firm value and financial performance and to test the ability of financial performance to mediate the relationship of intellectual capital with firm value which theoretically has a contribution to increase knowledge in the accounting world, specifically discussing related to value added information which is the output of Intellectual Capital and its influence on the optimization of financial performance and corporate value. In addition, this research is practically aimed at stakeholders to examine the importance of Intellectual Capital that encourages the business processes of an entity or company to be able to produce added value that gives more points to the company, while for subsequent researchers as a reference source in developing research in the field of Intellectual Capital.

\section{METHOD}

This study includes quantitative research using secondary data sources, in several property and real estate sub-sector companies included in the Indonesia Stock Exchange period 2015-2017 with a research period of approximately 4 months, from March to June 2019. The sample of companies in this study amounted to 31 companies with a purposive sampling technique, because there are several companies whose financial statements are incomplete so that 
Does The Value of the Company Affected Intellectual Capital with Financial Performance as Interesting Variables?

Junaedi, Nuraina, Sulistyowati

it becomes a consideration in determining the sample of companies to be studied. This study uses intervening variables with path analysis because path analysis is an extended regression analysis to estimate the causality relationship between variables that have been selected before, in accordance with existing theories and path analysis is included as part of a broad multiple regression analysis (Ghozali, 2013). This analysis directly occurs if 1 (one) variable influences other variables without using a connecting variable whereas indirectly it can occur if there are other variables mediating the two variables with an equation like the following:

Information:

$$
\begin{gathered}
R O A=\alpha+\beta 1 \text { VAICTM }+e 1 \rightarrow(1) \\
P B V=\alpha+\beta 2 \text { VAICTM }+\beta 3 R O A+e 2 \rightarrow(2)
\end{gathered}
$$

a. ROA (Return On Assets) as a proxy for financial performance.

b. VAICTM (Value Added Intellectual Coefficient) as a proxy for intellectual capital.

c. PBV (Price to Book Value) as a proxy for company value.

d. $\beta 1$ : path coefficient ROA and VAICTM

e. $\beta 2$ : path coefficient $P B V$ and VAICTM

f. $\beta 3$ : path coefficient $P B V$ and $R O A$

g. $e 1$ : residual profitability

h. 22 : residual value of the company

Mediation test through multiple test, to test the indirect effect of the independent variable with the dependent variable passing through the connecting variable which is calculated as follows:

Information:

$$
\mathrm{Sab}=\sqrt{\mathrm{b}^{2} \mathrm{Sa}^{2}+\mathrm{a}^{2} \mathrm{Sb}^{2}+\mathrm{Sa}^{2} \mathrm{Sb}^{2}}
$$

a. Sab : Standard error coefficient ab

b. a : coefficient a

c. $\mathrm{b}$ : coefficient $\mathrm{b}$

d. Sa : Standar error koefisien a

e. $\mathrm{Sb}$ : Standar error koefisien $\mathrm{b}$

\section{RESULT AND DISCUSSION}

A. Results of Analysis of Intellectual Capital Regression (X1) on Financial Performance (X2)

After conducting a partial significance test ( $\mathrm{t}$ test), the results obtained are a constant value and VAICTM of 0,000 which can be observed from table 1.

Table 1. Results ( $\mathrm{t}$ test)

\begin{tabular}{ccc}
\hline Model & $\mathrm{t}$ & Significant \\
& & \\
\hline Constant & $-15,505$ & 0,000 \\
VAICTM & 5,475 & 0,000 \\
\hline
\end{tabular}

Source: SPSS Version 22

Table 1 shows that the significance value is 0,000 below 0.05 , so it can be concluded that intellectual capital has a significant influence on financial performance. This is based on Resources Bassed Theory which states that a company can be said to excel in a stock market competition and produces good quality financial performance on condition of owning, controlling and being able to use all important assets (tangible or intangible assets), reinforced by Ozkan research, Cakan, \& Kayacan (2016) which states that the intellectual capital has a positive influence on ROA, the greater the intellectual capital, the profits created directly increase and the value of ROA also increases. 
Does The Value of the Company Affected Intellectual Capital with Financial Performance as Interesting Variables?

Junaedi, Nuraina, Sulistyowati

\section{B. Results of Analysis of Intellectual Capital Regression (X1) on Firm Value (Y)}

The partial significance test ( $t$ test) produces a constant value and VAICTM of 0,000, which is found in table 2 as follows:

Table 2. Results (t test)

Model $\quad t \quad$ Significant

\begin{tabular}{lll}
\hline Constant & $-4,418$ & 0,000 \\
VAICTM & 4,298 & 0,000 \\
\hline
\end{tabular}

Source: SPSS Version 22

Table 2 shows that the significance value obtained from the test was 0,000 below 0.05 . Thus it can be concluded that intellectual capital has a significant effect on firm value. Based on Satakeholder Theory which states that intellectual capital is believed to have an important influence in increasing the value of a company, in line with the opinion of Hamidah \& Sari (2014) which proves that intellectual capital is included in the source of knowledge, can significantly have an impact on increasing the wealth of a company, agree also with Nuryaman (2015) which states that intellectual capital has a positive influence on company value, and supported by Sudibya \& Restuti (2014) which proves that intellectual capital has a good influence on firm value. This is because the maximum utilization of intellectual capital can affect the attractiveness of investors, thereby directly increasing their perception of the value of a company.

C. Financial Performance mediates the relationship between Intellectual Capital and

\section{Company Value}

Testing the presence or absence of the influence of financial performance in mediating the relationship of intellectual capital to the value of the company, researchers look for the influence of financial performance first for the value of the company, then the next step is to do a mediation test and a sobel test.

1. Results of Analysis of Intellectual Capital Regression (X1) and Financial Performance (X2) Against Corporate Value/PBV (Y)

After a regression analysis the results obtained are constant values of 0.010 , VAICTM of 0.000 , and ROA of 0.705 which can be observed from table 3 .

Table 3. Intellectual Capital_IC Regression Model and Financial Performance of PBV

\begin{tabular}{llll}
\hline Model & Coefficient & $\mathrm{t}$ & Significant \\
\hline Constant & $-1,690$ & $-2,627$ & 0,010 \\
VAIC $^{\text {TM }}$ & 0,716 & 3,899 & 0,000 \\
ROA & $-0,043$ & $-0,379$ & 0,705 \\
\hline
\end{tabular}

Source: SPSS Version 22

Table 3 shows the multiple linear regression equation as follows:

$$
\mathrm{Y}=-1,690+0,716 \mathrm{VAIC}^{\mathrm{TM}}-0,043 \mathrm{ROA}
$$

The above equation is a model obtained from data that has been transformed to a $\log$ because at the beginning of testing the classical assumptions, the assumption of normality is not met. The equation with the anti-log value to return to the original data is as follows:

$$
\mathrm{Y}=0,185+2,046 \mathrm{VAIC}^{\mathrm{TM}}+1,044 \mathrm{ROA}
$$

Based on Table 3 and the above model can be explained if the variable intellectual capital and financial performance both have a value of 0 , so the variable $\mathrm{Y}$ or the value of the company (PBV) is worth 0.185. If intellectual capital (VAICTM) experiences an increase of 1 (one) unit, it 
Does The Value of the Company Affected Intellectual Capital with Financial Performance as Interesting Variables?

Junaedi, Nuraina, Sulistyowati

can cause the value of the company (PBV) to increase to 2,046 units provided the other variables are constant or zero. Then if the financial performance (ROA) has increased by 1 (one) unit, the company value (PBV) will experience a decrease of 1,044 units provided the other variables are constant or zero. Furthermore, after a partial significance test (t test) was obtained, the results obtained a constant value of 0.010 , VAICTM of 0.000 , and ROA of 0.705 as can be seen from table 4.

Table 4. Results ( $\mathrm{t}$ test)

\begin{tabular}{lll}
\hline Model & $\mathrm{t}$ & Significant \\
\hline Constant & $-2,627$ & 0,010 \\
VAIC $^{\text {TM }}$ & 3,899 & 0,000 \\
ROA & $-0,379$ & 0,705 \\
\hline
\end{tabular}

Source: SPSS Version 22

Table 4 shows the results of the $t$ test for the analysis of intellectual capital regression and financial performance to firm value (PBV). Variable intellectual capital_VAICTM t value is 3,899 and significance is 0,000 . Significant value of 0,000 is far below 0.05 so it can be concluded that the intellectual capital variable (VAICTM) partially has an influence on firm value (PBV) and the financial performance variable (ROA) has a $t$ value of -0.379 with a significance of 0.705 . The significance value of 0.705 exceeds the value of 0.05 so it can be concluded that financial performance (ROA) partially has no effect on the value of the company (PBV).

2. Mediation Test to Detect Influence of Financial Performance (ROA) in Mediating Intellectual Capital_VAICTM Relationship to Firm Value (PBV).

Mediation test is done by calculating the coefficient obtained from the results of intellectual capital regression to financial performance and the results obtained from the regression test of intellectual capital variables and financial performance to the company value whose results can be observed from table 5 .

Table 5. Intellectual Capital Regression Tests on Financial Performance

Model Coefficient Standard Error

\begin{tabular}{lll}
\hline Constant & $-4,854$ & 0,313 \\
VAIC $^{\text {TM }}$ & 0,810 & 0,148 \\
\hline
\end{tabular}

Sumber: SPSS Versi 22

Table 5 shows a value of 0.810 and $\mathrm{Sa}$ of 0.148 and other coefficient values needed for the test sobel are in the regression equation with the results shown in Table 6.

Table 6. Intellectual Capital_IC Regression Tests and Financial Performance of Company Values

\begin{tabular}{lll}
\hline & Koefisien & Standar Eror \\
\hline Constant & $-1,690$ & 0,643 \\
VAIC $^{\text {TM }}$ & 0,716 & 0,183 \\
ROA & $-0,043$ & 0,113 \\
\hline
\end{tabular}

Source: SPSS Version 22

Table 6 shows the coefficient $\mathrm{b}$ is -0.043 and the coefficient $\mathrm{Sb}$ is 0.113 . Then continue the sobel test as follows:

$$
\begin{gathered}
S a b=\sqrt{b^{2} S a^{2}+a^{2} S b^{2}+S a^{2} S b^{2}} \\
S a b=\sqrt{(-0,043)^{2} 0,148^{2}+0,810^{2} 0,113^{2}+0,148^{2} 0,113^{2}} \\
S a b=0,09326
\end{gathered}
$$


Does The Value of the Company Affected Intellectual Capital with Financial Performance as Interesting Variables?

Junaedi, Nuraina, Sulistyowati

The calculation using the formula above shows the value of the sobel test 0.09326 . Then proceed with the calculation of the value of $t$ which is done to test whether financial performance is able to mediate the relationship between intellectual capital and firm value.

$$
t=\frac{a b}{S a b}=\frac{(0,810)(-0,043)}{0,09326}=\frac{-0,03483}{0,0086979}=-0,37346
$$

The above calculation results in the calculated t value of $\mid-0.37346$ | or 0.37346 . Then compare with the value of $t$ table (significant 0.05 and degree freedom 157) of 1.986 so that it can be determined that the value of $t$ arithmetic (0.37346) is below the $t$ table (1.986). Thus, it can be concluded that there is no effect on the ROA_ financial performance in mediating the relationship of intellectual capital to the firm_PBV value.

Agree with Lestari (2017); Lestari \& Sapitri (2016) who did not succeed in proving the influence of IC on the value of the company, contrary to the results of research by Hadiwijaya \& Rohman (2013); Jayanti \& Binastuti (2017) which states that Intellectual Capital (IC) has a good influence on financial performance and corporate value.

\section{CONCLUSION}

Intellectual capital has a significantly positive effect on financial performance and firm value, while Intellectual capital does not have a significant influence on firm value through financial performance as an intervening variable because financial performance continues to increase and is stable does not mean that it can increase the value of a company and the value of a company is the perception of a number of investors regarding the success rate of a company that is often linked based on the level of stock prices, and that perception does not always occur only in the company's financial performance, but it can be from the quality of company management, resources, asset utilization or from other factors that attract investors in increasing their perception of a company.

The limitation of this study is that the researcher has difficulty in analyzing financial statements due to differences in terms of the accounts in the financial statements such as net income accounts written as net sales accounts at several companies. The next researcher is expected to learn more about the terms in writing accounts in the financial statements so that the differences in terms do not become obstacles in the process of analyzing the financial statements of each company.

\section{REFERENCE}

Andriana, D. (2014). Pengaruh Intellectual Capital Terhadap Kinerja Keuangan. Jurnal Riset Akuntansi Dan Keuangan, 2(1), 251-260. https://doi.org/10.17509/jrak.v3i2.6615

Brigham, \& Houston. (2010). Dasar-dasar Manajemen Kenangan. Jakarta: Salemba Empat.

Fahmi, I. (2018). Manajemen Kinerja Teori dan Aplikasi. Bandung: Alfabeta.

Febrianty, \& Divianto. (2020). Business Owner'S Perspective on Strategic Execution, Technological Transformation, Competitiveness Potential, and Services Level on the Implementation of Strategic It Alignment. Humanities \& Social Sciences Reviews, 8(1), 567-585. https://doi.org/10.18510/hssr.2020.8169_1

Ghozali, I. (2013). Aplikasi Analisis Multivariate dengan Program SPSS. Edisi Ketujuh. Semarang: Badan Penerbit Universitas Diponegoro.

Hadiwijaya, R. C., \& Rohman, A. (2013). Pengaruh Intellectual Capital Terhadap Nilai Perusahaan dengan KInerja Keuangan Sebagai Variabel Intervening. JDiponegoro Journal of Accounting, 2(3), 1-7. 
Does The Value of the Company Affected Intellectual Capital with Financial Performance as Interesting Variables?

Junaedi, Nuraina, Sulistyowati

Hamidah, \& Sari, D. P. (2014). Pengaruh Intellectual Capital Terhadap Kinerja Keuangan Pada Bank Go Public Yang Terdaftar Di Bursa Efek Indonesia (Bei) Tahun 2009-2012. Jurnal Riset Manajemen Sains Indonesia, 5(2), 186-203.

Hamidy, R. R., Wiksuana, I. G. B., \& Artini, L. G. S. (2015). Dengan Profitabilitas Sebagai Variabel Intervening Pada Perusahaan Properti Dan Real Estate Di Bursa Efek Indonesia. E-Jurnal Ekonomi Dan Bisnis Universitas Udayana, 4(10), 665-682.

Jayanti, L. D., \& Binastuti, S. (2017). Pengaruh Intellectual Capital Terhadap Nilai Perusahaan dengan Kinerja keuangan Sebagai Variabel Intervening pada Perusahaan Perbankan yang Terdaftar di Bursa Efek Indonesia. Jurnal Ekonomi Bisnis, 22(3), 187-198.

Lestari. (2017). Pengaruh Intellectual Capital \& Kepemilikan Institusional Terhadap Nilai Perusahaan. Jurnal Dinamika Ekonomi Dan Bisnis, 14(1), 17-39.

Lestari, N., \& Sapitri, R. C. (2016). Pengaruh Intellectual Capital Terhadap Nilai Perusahaan. Jurnal Akuntansi, Ekonomi Dan Manajemen Bisnis, 4(1), 28-33.

Ningrum, D. A. (2018). Ketidakpastian Global Bikin Saham Properti di Indonesia Melemah. Retrieved July 22, 2019, from www.merdeka.com website: https://www.merdeka.com/uang/ketidakpastian-global-bikin-saham-properti-diindonesia-melemah.html

Nuryaman. (2015). The Influence of Intellectual Capital on The Firm's Value with The Financial Performance as Intervening Variable. Procedia - Social and Behavioral Sciences, 211(September), 292-298. https://doi.org/10.1016/j.sbspro.2015.11.037

Ozkan, N., Cakan, S., \& Kayacan, M. (2016). Intellectual capital and financial performance: A study of the Turkish Banking Sector. Borsa Istanbul Review, 17(3), 190-198. https://doi.org/10.1016/j.bir.2016.03.001.

Sofyan, M. (2019). Rasio Keuangan Untuk Menilai Kinerja Keuangan. Jumal Akademika, 17(2), 115-121. Retrieved by http://jurnal.stieimalang.ac.id/index.php/JAK/article/view/173/97.

Sudibya, D. C. N. A., \& Restuti, M. M. D. (2014). Pengaruh Modal Intelektual Terhadap Nilai Perusahaan Dengan Kinerja Keuangan Sebagai Variabel Intervening. Benefit Jurnal Manajemen Dan Bisnis, 18(1), 14-29.

Ulum, I. (2009). Intellectual Capital. Yogyakarta: Graha Ilmu. 